\title{
ASXL1 Gene Mutation
}

National Cancer Institute

\section{Source}

National Cancer Institute. ASXL1 Gene Mutation. NCI Thesaurus. Code C97313.

A molecular genetic abnormality that refers to the presence of a mutation in the ASXL1 gene. 